\title{
EFFECT OF SILICON ON CROP YIELD, AND NITROGEN USE EFFICIENCY APPLIED UNDER STRAW RETURN TREATMENTS
}

\author{
MABAGala, F. S. ${ }^{1}-$ GENG, Y. H. ${ }^{*}{ }^{*}$ CAO, G. J. ${ }^{1 *}-$ WANG, L. C. ${ }^{2}-$ WANG, M. ${ }^{2}-$ ZHANG, M. L. $^{1}$ \\ ${ }^{1}$ College of Resources and Environment, Jilin Agricultural University, Changchun 130118, \\ China \\ ${ }^{2}$ Institute of Agricultural Environment and Resources Research, Jilin Academy of Agricultural \\ Sciences, Changchun 130033, China \\ *Corresponding authors \\ e-mail: gengyuhui@163.com; cgj72@126.com \\ (Received 30 $0^{\text {th }}$ Mar 2020; accepted $3^{\text {rd }}$ Jul 2020)
}

\begin{abstract}
Nitrogen $(\mathrm{N})$ is an essential element for crop growth and for improving crop yield. A two-year field experiment was carried out in China to test the effects of silicate ( $\mathrm{Si}$ ) fertilizer with straw return on $\mathrm{N}$ use efficiency (NUE) and yield of spring maize. Four treatments were arranged in a randomized block design: SI+ST (straw return $+45 \mathrm{~kg} \mathrm{ha}^{-1} \mathrm{Si}$ ), SI (no straw return $+45 \mathrm{~kg} \mathrm{ha}^{-1} \mathrm{Si}$ ), ST (straw return + no $\mathrm{Si}$ ) and $\mathrm{C}$ (no straw return + no $\mathrm{Si}$ ). The results showed that the accumulation of dry matter and grain yield under SI were $6.5 \%$ and $8.8 \%$ higher, respectively than those under the C. The N uptake under SI increased by $15.6 \%$ compared with that under the $\mathrm{C}$ treatment. The $\mathrm{N}$ uptake of SI+ST increased by $7.6 \%$ compared to SI. The SI+ST resulted in a significant increase in the AEN, REN, and PFPN compared with SI. The above results show that the use of $\mathrm{Si}$ fertilizer combined with straw return significantly provides better $\mathrm{N}$ for maize growing stages and is recommended as an alternative method to simultaneously increase crop yield and NUE while reducing the use of chemical fertilizer to the environment.
\end{abstract}

Keywords: crop residues, Si-based fertilizer, spring maize, $N$ utilization, grain yield

\section{Introduction}

Nitrogen $(\mathrm{N})$ is an essential nutrient for maize growth and is considered to be the main controlling factor for plant productivity after water deficiency (Lea and Azevedo, 2006). The high yield of the crop is associated with the application of a large amount of $\mathrm{N}$ fertilizers (Patel et al., 2017). The $\mathrm{N}$ use efficiency (NUE) of plants is the primary index used to determine nutrient uptake (Yang et al., 2003). It measures the ability of crops to accumulate and utilize nutrients for maximum yields (González-Fontes et al., 2017). NUE depends on the plant's ability to take up nutrients efficiently from the soil but also depends on internal transport, storage, and remobilization (Prieto et al., 2017). Thus, it involves three major processes in plants: uptake, assimilation, and utilization of nutrients (Baligar et al., 2001; Reich et al., 2014). Cereal NUE in china was approximately $41 \%$, and they're still the applying of excess $\mathrm{N}$ fertilizer, which has consequently resulted in low NUE (Omara et al., 2019). Many measures have been recommended to enhance plant NUE including proper management of rhizosphere processes (Zhu et al., 2010), the use endophytic bacteria (Prieto et al., 2017), conservation agriculture (Jat et al., 2012), through alteration of amino acid transport processes (Perchlik and Tegeder, 2017) and the use of split application of reduced nitrogen (Du et al., 2019b). Therefore, the best $\mathrm{N}$ fertilizer management practice has to be adopted to improve NUE in crops. Management of $\mathrm{N}$ is a complex task, and several approaches individually and in combination, have been engaged to manage its effectiveness (Sharma and Bali, 2018). 
Silicon ( $\mathrm{Si}$ ) is the most abundant element on the earth's surface, which has proved to have many beneficial effects for crops (Deshmukh et al., 2017). Si has been reported to have a significant effect on yield and modify growth in crops (Luz et al., 2008). Previous research has discovered that $\mathrm{Si}$ can stimulate various plants to take up more macronutrients and micronutrients $(\mathrm{Ca}, \mathrm{P}, \mathrm{S}, \mathrm{Mn}, \mathrm{Zn}, \mathrm{Cu}, \mathrm{Cl}, \mathrm{Fe}$ ) from the soil (Islam and Saha, 1969; Owino-Gerroh and Gascho, 2005; Greger et al., 2018). According to previous studies (Singh et al., 2006; Jugal and Ramani, 2017; Patel et al., 2017), the application of $\mathrm{Si}$ has a synergistic relationship with $\mathrm{N}$ in rice. Recent studies have shown that Silicon (Si) also influenced the nutrient uptake and accumulation in non-stressed crops (Greger et al., 2018). Si enhances NUE, $\mathrm{P}$ availability, and carbon turnover in wheat crops (Neu et al., 2017). Si application influenced the availability of $\mathrm{N}$ uptake, which enhances the increase of biomass and prevents $\mathrm{N}$ starvation in plants (Haddad et al., 2018).

Crop straw is rich in plant nutrients such as nitrogen, phosphorus, and potassium, and many trace elements (Gao et al., 2009). Wang et al. (2019) reported that straw return remarkably increased $\mathrm{N}$ uptake and grain yield in maize-wheat rotation. The combination of organic and inorganic fertilizers enhanced the $\mathrm{N}$ uptake, the $\mathrm{N}$ use, and recovery from the soil in rice (Moe et al., 2017). Incorporation of straw into soil improved the NUE and carbon inputs (Eagle et al., 2001). Apart from the increased NUE, the use of wheat straw significantly increased the nitrogen agronomic efficiency (AEN), the nitrogen recovery efficiency (REN), the nitrogen physiological efficiency (PEN), and the nitrogen partial factor productivity (PFPN) (Hu and Zhang, 2017). Appropriate management of organic matter ensures conservation and provisions nutrients in a prolonged period in crop production (Watson et al., 2002).

The enhancement of NUE in crops has been shown mainly by the application of Si or straw individually in previous researches. There is currently no research on $\mathrm{Si}$ combined with straw return on NUE in crops. We hypothesized that though apply Si could stimulate plants to take up more $\mathrm{N}$ from the soil, however, due to the fixation of silicon fertilizer in the soil, its effect only lasts for a short time. The straw can not only increase the nutrients in the soil but can also improve $\mathrm{Si}$ availability at the late stages of growth. Thus, meet crop needs and enhance plant growth and development in later stages and sustainably enhance grain yield. The main objective of the study was to investigate the effect of silicate fertilizer with straw on $\mathrm{N}$ uptake, remobilization, NUE, and yield in spring maize. The findings of the study could add to the development strategies that improve NUE and sustainably to enhance crop yield.

\section{Materials and Methods}

\section{Experimental design and crop management}

Two field trials were established at Dong Fang Hong village (124 ' 31 'E, $\left.43{ }^{\circ} 55^{\prime}\right)$, Nong'an County, Changchun city, Jilin Province in China, in the 2017 and 2018 growing seasons. The soil was Chernozem (soil classification is based on the Canadian system of soil classification) (Haynes, 1998) containing 27.96 and $25 \mathrm{~g} \mathrm{~kg}^{-1}, 107.31$ and $109.2 \mathrm{mg}$ $\mathrm{kg}^{-1}$ alkaline nitrogen $(\mathrm{N}), 50.73$ and $33.9 \mathrm{mg} \mathrm{kg}^{-1}$ available phosphorus (P), 163.59 and $114.1 \mathrm{mg} \mathrm{kg}^{-1}$ available potassium (K), 350.19 and $357 \mathrm{mg} \mathrm{kg}^{-1}$ available silicon ( $\mathrm{Si}$ ), 8.02 and 7.7 soil $\mathrm{pH}$ before maize planting at a soil depth $0-20 \mathrm{~cm}$ in 2017 and 2018, respectively. Spring maize is the maize grown during the spring season and are sensitive to climate change. 
The experiments had a two-way factorial design in which $12000 \mathrm{~kg} \mathrm{ha}^{-1}(\mathrm{~J})$ of straw was returned to the field in one area, and the other area had no straw returned to the field (W). The Si treatments included the S0 treatment $\left(0 \mathrm{~kg} \mathrm{ha}^{-1}\right.$, no Si fertilizer) and the S3 treatment (45 kg ha ${ }^{-1}$ of Si fertilizer). There were four treatments: C (no Si fertilizer + no straw), SI (Si fertilizer + no straw), ST (no Si fertilizer + straw) and SI+ST (Si fertilizer + straw). The treatments were arranged in a randomized block design (RBD) with three replications. Sodium silicate $\left(\mathrm{Na}_{2} \mathrm{SiO}_{3}\right)$ was used as Si fertilizer. The area of each plot was $35 \mathrm{~m}^{2}$. The maize variety Fumin 985 (produced by Jilin Fumin Seed Leaf Co., Ltd) was planted on May 7, 2017, and May 10, 2018, and then harvested on September 28, 2017, and October 2, 2018, respectively. The planting density was 65000 plants ha ${ }^{-1}$. Macronutrients (nitrogen, phosphorus, and potassium) were applied in the experimental plots. The rate of $\mathrm{N}$ application was $240 \mathrm{~kg} \mathrm{ha}^{-1}$ in each treatment, in which the base fertilizer accounted for $40 \%$ of the total $\mathrm{N}$ application rate, the topdressing fertilizer at the jointing stage accounted for $30 \%$ of the total $\mathrm{N}$ application rate, and the topdressing fertilizer at the heading stage accounted for $30 \%$ of the total $\mathrm{N}$ application rate. All plots were treated with phosphorus pentoxide $\left(\mathrm{P}_{2} \mathrm{O}_{5}, 100 \mathrm{~kg} \mathrm{ha}^{-1}\right)$ and potassium oxide $\left(\mathrm{K}_{2} \mathrm{O}, 100 \mathrm{~kg} \mathrm{ha}^{-1}\right)$, which were applied once as the base fertilizers. The remainder of the management was based on the high standard of field production.

\section{Plant sampling and tissue nutrient analysis}

Three samples of fresh plants were collected from each plot at growth stages V6 (six leaves), V12 (twelve leaves), VT (tasseling), R2 (blister aging), R3 (milking) and R6 (maturity) (June 29, July 18, July 27, August 22, September 7, and September 27 in 2017 and July 15, July 24, August 2, August 23, September 11, and September 28 in 2018, respectively). Plant samples were divided into four components: stem (including the stem, leaf sheath, and bract leaf), leaf, cob, and grain. Plant samples were heated at a constant temperature in a blast oven at $105^{\circ} \mathrm{C}$ for $30 \mathrm{~min}$ and dried to a uniform weight at $80{ }^{\circ} \mathrm{C}$. Each plant piece was weighed to obtain its dry weight (DW). The total $\mathrm{N}$ content of the different plant organs was extracted by the Kjeldahl method.

\section{Grain yield and yield components}

At maize maturity, the yield was measured in each experimental plot with a representative area of $10 \mathrm{~m}^{2}$, and ten ears were selected according to the weight mean method to measure the grain number per ear and the 1000-grain weight. The economic yield was calculated by the air-dry weight (14\% water content) of 10 grains in each plot.

\section{Calculations}

(Mi et al., 2003; Chen et al., 2014; Agegnehu et al., 2016; Du et al., 2016, 2019a; Deng et al., 2018).

\section{Nitrogen change and $N$ remobilization}

To model the $\mathrm{N}$ uptake pattern, a logistic model was used to describe the progress of the plant $\mathrm{N}$ uptake as follows:

$$
N=\frac{N_{\max }}{1+a e^{b t}}
$$




$$
\begin{aligned}
& t_{1}=-\frac{1}{b} \ln \frac{2+\sqrt{3}}{a} \\
& t_{2}=-\frac{1}{b} \ln \frac{2-\sqrt{3}}{a}
\end{aligned}
$$

where is the $\mathrm{N}$ uptake in maize, $\mathrm{N}_{\max }\left(\mathrm{kg} \mathrm{ha}^{-1}\right)$ is the asymptotic maximum $\mathrm{N}$ uptake by maize, and $\mathrm{a}$ and $\mathrm{b}$ are the constants to be determined. The time of the $\mathrm{N}$ uptake rate acceleration is $t_{1}$, the time of the $\mathrm{N}$ uptake rate deceleration is $t_{2}, t_{2}-t_{1}$ is the fast uptake duration of maize $\mathrm{N}$.

$\mathrm{N}$ accumulation amount in the plant,

$$
\begin{aligned}
& \text { NAA }\left(\mathrm{kg} \mathrm{ha}^{-1}\right)=\text { Plant dry weight }\left(\mathrm{kg} \mathrm{ha}^{-1}\right) \times \text { Plant } \mathrm{N} \text { content }(\%) \\
& \mathrm{N} \text { remobilization amount }\left(\mathrm{kg} \mathrm{ha}^{-1}\right)=\text { maximum } \mathrm{N} \text { content during } \\
& \text { the growth period }-\mathrm{N} \text { content at maturity } \\
& \mathrm{N} \text { remobilization efficiency }(\%)=(\text { maximum } \mathrm{Mg} \text { content during } \\
& \text { the growth period }-\mathrm{Mg} \text { content at maturity) } / \text { maximum } \mathrm{Mg} \\
& \text { content during the growth period } \times 100 \\
& \text { Apparent contribution to grain by } \mathrm{N} \text { remobilization }(\%)= \\
& (\text { maximum } \mathrm{N} \text { content during the growth period }-\mathrm{N} \text { content at } \\
& \text { maturity)/grain } \mathrm{N} \text { content at maturity } \times 100
\end{aligned}
$$

\section{Nitrogen use efficiency}

The AEN, REN, PEN, and PFPN were computed using the below formulas:

$$
\begin{gathered}
P F P N=\frac{Y T}{F N} \\
A E N=\frac{A Y}{N A} \\
R E N=\frac{A N U}{N A} \\
P E N=\frac{A Y}{A N U}
\end{gathered}
$$

where, AEN is the increased maize grain yield $(\Delta \mathrm{Y})$ over zero- $\mathrm{N}$ plots per unit area of fertilizer $\mathrm{N}$ applied (NA). REN is the increased total $\mathrm{N}$ uptake over zero-N plots $(\Delta N U)$. PFPN is the maize total grain yield (YT) per unit area of fertilizer $\mathrm{N}$ applied (FN) $\mathrm{Kg}$ of $\mathrm{N}$ per ha applied. PEN is the increased maize grain yield per unit area $(\Delta \mathrm{Y})$ of increased $\mathrm{N}$ uptake over zero- $\mathrm{N}$ plots $(\Delta \mathrm{NU})$. 


\section{Statistical data analysis}

Total $\mathrm{N}$ accumulation $\left(\mathrm{kg} \mathrm{ha}^{-1}\right)$, remobilization amount $\left(\mathrm{kg} \mathrm{ha}^{-1}\right)$, remobilization efficiency (\%), apparent transfer to the grain (\%) and total dry matter accumulation $\left(\mathrm{kg} \mathrm{ha}^{-1}\right)$ at different growth stages and the grain yield and yield components were analyzed using SPSS Statistics 25.0 (SPSS, Inc., Chicago, IL, USA). Differences in mean C, SI, ST, and SI+ST treatments were tested for statistical significance by analysis of variance (ANOVA). One-way ANOVA was used to test for differences in mean C, SI, ST, and SI+ST during the maize growth. Two-way ANOVA was used to test for the effects of Si fertilizer, straw return, and their interaction of mean C, SI, ST, and SI+ST. In case of significant differences among the means, DUNCAN significant differences at $P=0.05$ test was used. Figures were created in Origin Pro 8. Means and standard errors (S.E) from the statistical analysis were brought into Origin Pro 8, and diagrams were created using the line+ symbol and column graph tools.

\section{Results}

\section{Maize grain yield components}

As shown in Table 1, the yield of Si-fertilized treatments was higher than that without silicate fertilizer. Compared with the $\mathrm{C}$ with an average yield of $11124 \mathrm{~kg} \mathrm{ha}^{-1}$, the corn yield of SI treatment was higher, with an average yield of $11671 \mathrm{~kg} \mathrm{ha}^{-1}$ in two years (Table 1). In both years, significant differences in grain number and 1000-grain weight observed between Si-fertilized treatments and treatments without $\mathrm{Si}$ fertilizer. The two-year average yield of the SI+ST treatment $\left(11829 \mathrm{~kg} \mathrm{ha}^{-1}\right)$ was higher than that of the SI treatment (11671 $\mathrm{kg} \mathrm{ha}^{-1}$ ) (Table 1). Averaged over two years, the crop productivity of SI increased by $4.8 \%$ on average compared with that of $\mathrm{C}$ (Table 1).

Table 1. Showing variance analysis of grain number (per ear), 1000-grain weight (g), and yield $\left(\mathrm{kg} \mathrm{ha}^{-1}\right)$, and increased productivity of maize in two consecutive years of 2017-2018

\begin{tabular}{c|c|c|c|c|c}
\hline Year & Treatment & $\begin{array}{c}\text { Grain Number } \\
\text { (per Ear) }\end{array}$ & $\begin{array}{c}\text { 1000-Grain Weight } \\
(\mathbf{g})\end{array}$ & $\begin{array}{c}\text { Yield } \\
\left(\mathbf{k g ~ h a}^{-1}\right)\end{array}$ & $\begin{array}{c}\text { Increased } \\
\text { Productivity (\%) }\end{array}$ \\
\hline \multirow{3}{*}{2017} & $\mathrm{C}$ & $597 \pm 4 \mathrm{c}$ & $300 \pm 11 \mathrm{c}$ & $11196 \pm 359 \mathrm{c}$ & - \\
& $\mathrm{SI}$ & $597 \pm 14 \mathrm{c}$ & $330 \pm 7 \mathrm{a}$ & $11685 \pm 221 \mathrm{a}$ & 4.4 \\
& $\mathrm{ST}$ & $635 \pm 5 \mathrm{~b}$ & $314 \pm 2 \mathrm{~b}$ & $11345 \pm 11 \mathrm{~b}$ & 1.3 \\
& $\mathrm{SI}+\mathrm{ST}$ & $693 \pm 33 \mathrm{a}$ & $330 \pm 4 \mathrm{a}$ & $11881 \pm 107 \mathrm{a}$ & 6.1 \\
\hline \multirow{3}{*}{2018} & $\mathrm{C}$ & $329 \pm 6 \mathrm{~b}$ & $527 \pm 3 \mathrm{c}$ & $11052 \pm 155 \mathrm{c}$ & - \\
& $\mathrm{SI}$ & $336 \pm 4 \mathrm{ab}$ & $550 \pm 8 \mathrm{a}$ & $11657 \pm 30 \mathrm{a}$ & 5.3 \\
& $\mathrm{ST}$ & $333 \pm 21 \mathrm{ab}$ & $542 \pm 62 \mathrm{~b}$ & $11067 \pm 24 \mathrm{~b}$ & 0.1 \\
& $\mathrm{SI}+\mathrm{ST}$ & $346 \pm 4 \mathrm{a}$ & $556 \pm 2 \mathrm{a}$ & $11777 \pm 134 \mathrm{a}$ & 6.4 \\
\hline
\end{tabular}

\section{Total dry matter accumulation in maize}

Dry matter accumulation was affected by $\mathrm{Si}$ and straw applications over the two experimental years (Fig. 1). All the treatments showed a similar trend of total biomass accumulation in maize. At the V6 stage, the level of dry matter was low, and there were no differences among treatments; then, the biomass increased continuously with the age of the maize plant until maturity, and the differences between different treatments 
gradually increased. At harvest time, the dry matter accumulation under the SI treatment increased by $6.1 \%$ on average compared to that under the $\mathrm{C}$ treatment. The total dry matter under the SI+ST treatment increased by $2.9 \%$ on average compared with that under the SI treatment. In both years, there was a significant difference between the straw application treatments and those with no straw.
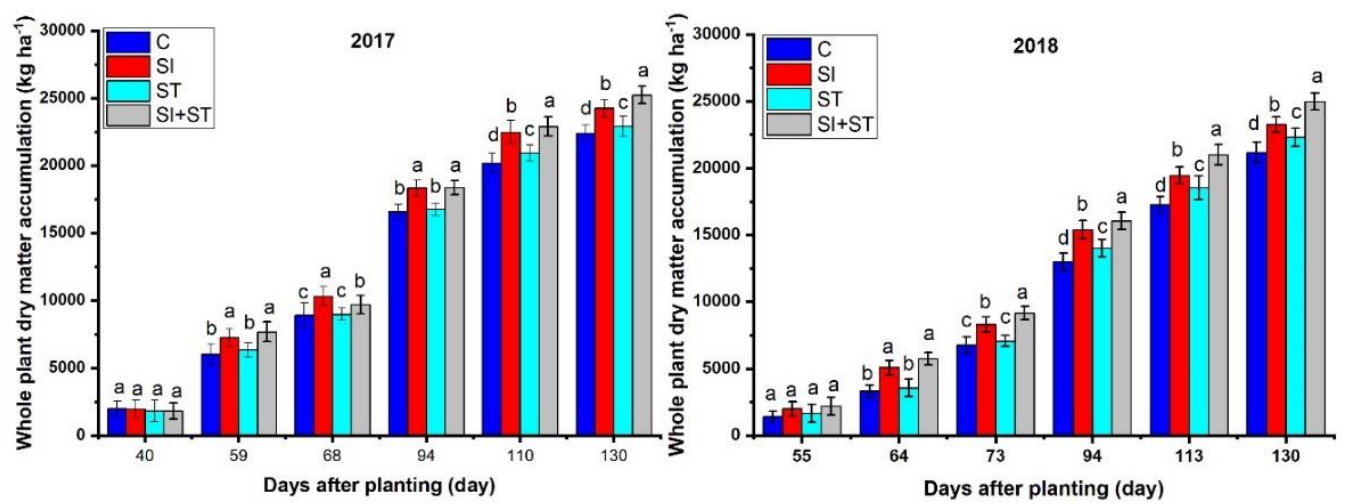

Figure 1. The seasonal total dry matter accumulation of Si evaluated for two years, 2017 and 2018. Values are means with standard deviations shown by vertical bars $(n=4)$. Bars with a different lowercase letter $(s)$ in the same planting date indicate significant differences at $P<$ 0.05 among the treatments

\section{Total $N$ uptake and total $N$ uptake rate in spring maize}

$\mathrm{N}$ uptake in maize increased from the V6 stage to physiological maturity, and there were significant differences among the $\mathrm{Si}$ and straw treatments. The $\mathrm{N}$ uptake of the SI treatment was $15.9 \%$ higher than that of the $\mathrm{C}$ treatment at the maturity stage. The effect of the straw application on maize $\mathrm{N}$ uptake was significant (Fig. 2). The $\mathrm{N}$ uptake under the SI+ST treatment increased by $7.7 \%$ compared to that under SI treatment. During the period of the fast $\mathrm{N}$ uptake stage, the uptake rate under the SI treatment had a mean rate of $10.4 \%$ higher than that under the $\mathrm{C}$ treatment in both years. In comparison with the SI treatment, the SI+ST treatment showed a noticeable increase in N uptake by the crop. The uptake rate of SI+ST treatment had a mean rate of 3.8\% higher than that of SI treatment, averaged over two years.
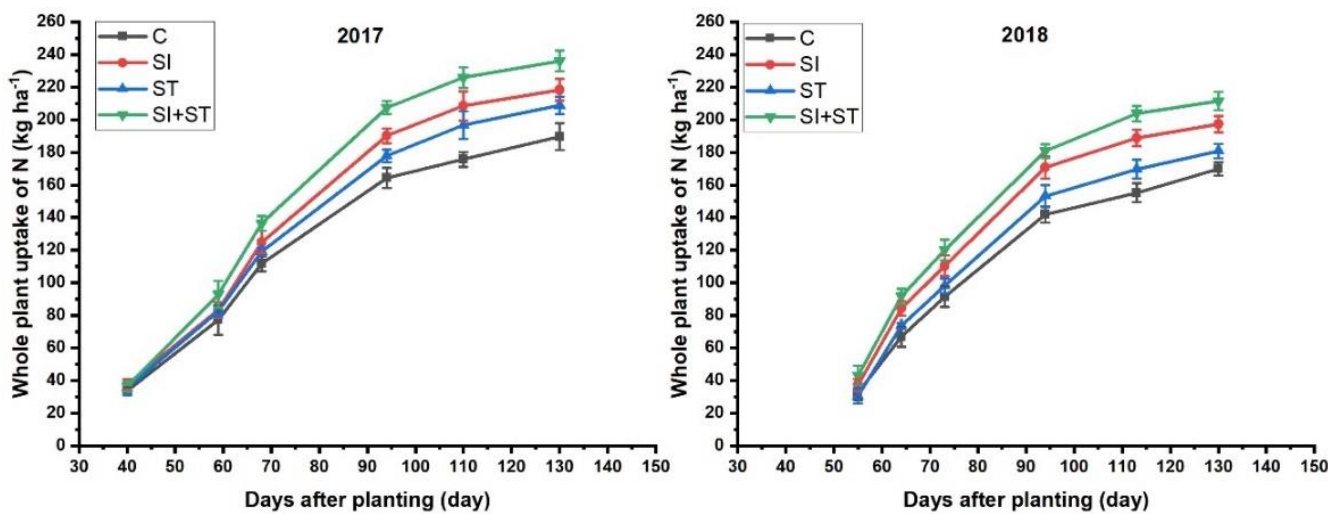

Figure 2. The response of maize total plant $N$ uptake for two years, 2017 and 2018. Each data point is the mean \pm S.E. of three replications 


\section{$N$ remobilization in spring maize}

The result showed that the remobilization of nitrogen in leaves and stems in two years under all treatments manifested the same tendency ( $\mathrm{SI}+\mathrm{ST}>\mathrm{SI}>\mathrm{ST}>\mathrm{C})$ (Table 2). Averaged over two years, the remobilization amount, the remobilization efficiency, and contribution to the grain under the SI treatment increased by $21 \%, 4 \%$, and $6.8 \%$, respectively, compared to the conventional practice application (C). The remobilization amount, the remobilization efficiency, and the contribution to the grain under the plots treated with straw increased by $7.9 \%, 1.1 \%$, and $3.6 \%$, respectively, compared to that with no straw when averaged over two years.

Table 2. Analysis of variance of the vegetative Si remobilization amount $\left(m g \mathrm{~kg}^{-1}\right)$, remobilization efficiency (\%) and contribution to the grain (\%) in two successive years (20172018)

\begin{tabular}{|c|c|c|c|c|c|c|c|c|c|c|}
\hline & \multicolumn{4}{|c|}{$\begin{array}{l}\text { N remobilization Amount } \\
\qquad\left(\mathrm{kg} \mathrm{ha}^{-1}\right)\end{array}$} & \multicolumn{3}{|c|}{$\begin{array}{c}\text { N remobilization efficiency } \\
(\%)\end{array}$} & \multicolumn{3}{|c|}{$\begin{array}{c}\text { Apparent contribution to } \\
\text { grain } \mathbf{N} \text { by } \mathbf{N} \text { remobilization } \\
(\%)\end{array}$} \\
\hline \multirow{9}{*}{2017} & \multirow{3}{*}{$\mathrm{C}$} & leaves & stem & total & leaves & stem & total & leaves & stem & total \\
\hline & & $31.7 \pm$ & $15.5 \pm$ & $47.2 \pm$ & $41.2 \pm$ & $50.6 \pm$ & $44.4 \pm$ & $29.6 \pm$ & $19.3 \pm$ & $48.9 \pm$ \\
\hline & & $0.53 b$ & $0.95 b$ & $0.66 \mathrm{c}$ & $1.29 \mathrm{a}$ & $0.66 b$ & $1.62 \mathrm{a}$ & $0.15 \mathrm{c}$ & $0.21 \mathrm{~d}$ & $0.41 \mathrm{~d}$ \\
\hline & \multirow{2}{*}{ SI } & $40.3 \pm$ & $17.9 \pm$ & $58.2 \pm$ & $42.6 \pm$ & $52.0 \pm$ & $45.7 \pm$ & $33.6 \pm$ & $19.8 \pm$ & $53.4 \pm$ \\
\hline & & $0.43 b$ & $0.27 \mathrm{ab}$ & $0.39 b$ & $1.28 \mathrm{~b}$ & $1.67 \mathrm{c}$ & $1.48 \mathrm{c}$ & $0.04 \mathrm{~b}$ & $0.25 b$ & $0.12 b$ \\
\hline & \multirow{2}{*}{$\mathrm{ST}$} & $36.4 \pm$ & $14.00 \pm$ & $50.4 \pm$ & $42.0 \pm$ & $47.8 \pm$ & $43.9 \pm$ & $31.9 \pm$ & $18.5 \pm$ & $50.4 \pm$ \\
\hline & & $0.24 b$ & $0.17 \mathrm{c}$ & $0.24 d$ & $1.54 \mathrm{a}$ & $1.49 \mathrm{a}$ & $1.18 \mathrm{~b}$ & $0.11 b$ & $0.07 \mathrm{c}$ & $0.10 \mathrm{c}$ \\
\hline & \multirow{2}{*}{$\mathrm{SI}+\mathrm{ST}$} & $44.1 \pm$ & $17.4 \pm$ & $61.5 \pm$ & $43.1 \pm$ & $52.4 \pm$ & $46.1 \pm$ & $34.6 \pm$ & $20.3 \pm$ & $54.9 \pm$ \\
\hline & & $0.03 \mathrm{a}$ & $0.45 \mathrm{a}$ & $0.21 \mathrm{a}$ & $0.41 \mathrm{~b}$ & $1.19 \mathrm{~b}$ & $1.17 \mathrm{c}$ & $0.20 \mathrm{a}$ & $0.34 \mathrm{a}$ & $0.23 \mathrm{a}$ \\
\hline \multirow{8}{*}{2018} & \multirow{2}{*}{$\mathrm{C}$} & $26.8 \pm$ & $18.3 \pm$ & $45.1 \pm$ & $39.2 \pm$ & $47.8 \pm$ & $42.3 \pm$ & $28.2 \pm$ & $19.2 \pm$ & $47.4 \pm$ \\
\hline & & $0.76 \mathrm{c}$ & $1.91 \mathrm{c}$ & $1.35 \mathrm{c}$ & $1.31 \mathrm{a}$ & $0.97 \mathrm{a}$ & $2.51 \mathrm{a}$ & $0.19 \mathrm{c}$ & $0.23 c$ & $0.49 \mathrm{c}$ \\
\hline & \multirow{2}{*}{ SI } & $32.8 \pm$ & $22.8 \pm$ & $55.6 \pm$ & $40.8 \pm$ & $51.3 \pm$ & $44.5 \pm$ & $29.2 \pm$ & $20.3 \pm$ & $49.5 \pm$ \\
\hline & & $0.96 \mathrm{ab}$ & $1.87 \mathrm{ab}$ & $1.87 \mathrm{a}$ & $0.83 \mathrm{c}$ & $0.22 b$ & $1.41 \mathrm{c}$ & $0.05 \mathrm{~b}$ & $0.22 b$ & $0.22 b$ \\
\hline & \multirow{2}{*}{ ST } & $30.0 \pm$ & $20.8 \pm$ & $50.8 \pm$ & $38.7 \pm$ & $51.1 \pm$ & $43.0 \pm$ & $28.8 \pm$ & $20.0 \pm$ & $48.8 \pm$ \\
\hline & & $0.90 \mathrm{~b}$ & $1.39 b c$ & $1.82 \mathrm{~b}$ & $0.40 \mathrm{~b}$ & $0.25 b$ & $2.57 \mathrm{~b}$ & $0.04 \mathrm{~b}$ & $0.25 b$ & $0.10 \mathrm{~b}$ \\
\hline & \multirow{2}{*}{$\mathrm{SI}+\mathrm{ST}$} & $35.6 \pm$ & $25.7 \pm$ & $61.3 \pm$ & $41.0 \pm$ & $52.1 \pm$ & $45.1 \pm$ & $30.0 \pm$ & $21.7 \pm$ & $51.7 \pm$ \\
\hline & & $4.33 \mathrm{a}$ & $1.95 \mathrm{a}$ & $0.68 \mathrm{a}$ & $1.51 \mathrm{a}$ & $0.23 c$ & $3.28 \mathrm{~d}$ & $0.21 \mathrm{a}$ & $0.97 \mathrm{a}$ & $0.29 a$ \\
\hline \multicolumn{11}{|c|}{ Anova } \\
\hline \multicolumn{2}{|c|}{$\mathrm{F}$} & NS & $* *$ & $*$ & $* *$ & $* *$ & $* *$ & $* *$ & $* *$ & $* *$ \\
\hline \multicolumn{2}{|c|}{ S } & $* *$ & NS & $* *$ & NS & $* *$ & $* *$ & $* *$ & $*$ & $* *$ \\
\hline \multicolumn{2}{|c|}{$\mathrm{FS}$} & NS & NS & NS & $*$ & NS & NS & $* *$ & $* *$ & $* *$ \\
\hline \multicolumn{2}{|c|}{ FSY } & $*$ & $*$ & NS & NS & NS & NS & $* *$ & $* *$ & $* *$ \\
\hline
\end{tabular}

Note: F: fertilizer, S: straw, $\mathrm{F} \times \mathrm{S}$ : fertilizer with straw, FSY: fertilizer $\times$ straw $\times$ year. NS, not significant (p-value $>0.05) ; *$, significant at (p-value $<0.05) ; * *$, significant at $(\mathrm{p}$-value $<0.01)$

\section{$N$ use efficiency (NUE) in spring maize}

The data indicated that the AEN, REN, and PFPN were significantly increased with the Si fertilizer application (Table 3). Compared to the C treatment, the SI treatment resulted in increases in AEN, REN, and PFPN of 13.6\%, 44.9\%, and 4.9\%, respectively, averaged over two years. The PEN under SI treatment decreased by $26.7 \%$ compared to that of the $\mathrm{C}$ treatment, averaged over two years. The AEN, REN, and PFPN of the SI+ST treatment increased by $3.6 \%, 17.6 \%$, and $1.3 \%$, respectively, compared to that under SI treatment. the PEN decreased under the SI+ST treatment by $13.5 \%$ when averaged in two years. 
Table 3. Variance analysis of the $N$ use efficiencies (Eq.8,9,10 and 11); - agronomic use efficiency $\left(\mathrm{mg} \mathrm{k}^{-1}\right)$, recovery use efficiency (\%), and physiological use efficiency $\left(\mathrm{kg} \mathrm{ha} \mathrm{h}^{-1}\right)$, and partial factor productivity of $N(P F P N)$ in two consecutive years of 2017-2018

\begin{tabular}{|c|c|c|c|c|c|}
\hline & Treatments & $\begin{array}{c}\text { Agronomic N Use } \\
\text { Efficiency (AEN) } \\
\mathrm{kg} \mathrm{kg}^{-1}\end{array}$ & $\begin{array}{c}\text { Recovery N Use } \\
\text { Efficiency } \\
\text { (REN) \% }\end{array}$ & $\begin{array}{l}\text { Physiological N } \\
\text { Use Efficiency } \\
\text { (PEN) kg kg-1 }\end{array}$ & $\begin{array}{l}\text { N partial factor } \\
\text { productivity } \\
\text { (PFPN) } \mathrm{kg} \mathrm{kg}^{-1}\end{array}$ \\
\hline \multirow{4}{*}{2017} & $\mathrm{C}$ & $16.03 \pm 0.09 \mathrm{c}$ & $26.99 \pm 0.25 \mathrm{~d}$ & $59.39 \pm 0.15 a$ & $46.65 \pm 0.37 d$ \\
\hline & SI & $18.07 \pm 0.14 \mathrm{ab}$ & $38.89 \pm 0.68 b$ & $46.46 \pm 0.26 b$ & $48.69 \pm 0.33 b$ \\
\hline & ST & $16.65 \pm 0.04 \mathrm{~b}$ & $34.94 \pm 0.29 \mathrm{c}$ & $47.65 \pm 014 b$ & $47.27 \pm 0.17 \mathrm{c}$ \\
\hline & $\mathrm{SI}+\mathrm{ST}$ & $18.88 \pm 0.37 \mathrm{a}$ & $46.29 \pm 0.19 \mathrm{a}$ & $40.78 \pm 0.02 \mathrm{c}$ & $49.50 \pm 1.29 \mathrm{a}$ \\
\hline \multirow{4}{*}{2018} & $\mathrm{C}$ & $15.78 \pm 0.07 \mathrm{c}$ & $24.95 \pm 0.16 \mathrm{~d}$ & $63.23 \pm 0.03 a$ & $46.05 \pm 0.08 \mathrm{c}$ \\
\hline & SI & $18.30 \pm 0.18 \mathrm{~b}$ & $36.36 \pm 0.12 b$ & $50.32 \pm 0.22 \mathrm{c}$ & $48.57 \pm 0.22 b$ \\
\hline & ST & $15.85 \pm 0.23 \mathrm{c}$ & $29.52 \pm 0.21 \mathrm{c}$ & $53.68 \pm 0.17 b$ & $46.11 \pm 0.03 c$ \\
\hline & $\mathrm{SI}+\mathrm{ST}$ & $18.80 \pm 0.37 \mathrm{a}$ & $42.28 \pm 0.02 \mathrm{a}$ & $44.46 \pm 0.32 \mathrm{~d}$ & $49.07 \pm 0.004 \mathrm{a}$ \\
\hline \multicolumn{2}{|r|}{ Anova } & & & & \\
\hline & $\mathrm{F}$ & $* *$ & $* *$ & $* *$ & $* *$ \\
\hline & $S$ & $*$ & $* *$ & $* *$ & $* *$ \\
\hline & F S & NS & NS & $* *$ & $*$ \\
\hline & FSY & NS & $*$ & $* *$ & NS \\
\hline
\end{tabular}

F: fertilizer, S: straw, $\mathrm{F} \times \mathrm{S}$ : fertilizer with straw, FSY: fertilizer $\times$ straw $\times$ year. NS, not significant $(\mathrm{p}-$ value $>0.05) ; *$, significant at $(\mathrm{p}$-value $<0.05) ; * *$, significant at $(\mathrm{p}$-value $<0.01)$

\section{Discussion}

\section{Maize biomass yield, grain yield, and increased productivity}

Silicon ( $\mathrm{Si}$ ) is closely related to plant growth and yield owing to strengthen the physiological attributes of the maize (Kaya et al., 2006; Amin et al., 2016). Si has proved to enhance the photosynthesis process, improves the absorption of nutrients, and increases grain yield in maize (Xu et al., 2016). The results present in Table 1 illustrate that the maize grain and dry matter significantly influenced by Si application. The substantially higher grain yield (11685 kg ha-1 and $\left.11657 \mathrm{~kg} \mathrm{ha}^{-1}\right)$ in 2017 and 2018 were recorded due to the basal application of Si, while the lower grain $\left(11196 \mathrm{~kg} \mathrm{ha}^{-1}\right.$ and $\left.11052 \mathrm{~kg} \mathrm{ha}^{-1}\right)$ were registered under the conventional practice. The treatment SI gave a $6.5 \%$ higher dry matter over C (Fig. 1). The result was consistent of the report by $\mathrm{Xu}$ et al. (2016), who found that the application of Si improved maize grain yield and dry matter accumulation.

Huang et al. (2010) mentioned the application of organic fertilizer combined with inorganic fertilizer is a good fertilization practice for modifying soil quality and attaining optimum yield. Many reports have shown that straw return provides nutrients, and it's associated with improved biomass yield and grain yield (Zhang et al., 2009; Xu et al., 2010; Wang et al., 2018). The findings from this trial demonstrate that the addition of Si fertilizer and straw increases grain yield and dry matter of maize in two years (Table 1). The significantly higher grain (11881 kg ha-1 and $\left.11777 \mathrm{~kg} \mathrm{ha}^{-1}\right)$ in 2017 and 2018 were recorded due to the addition of organic matter by straw application (Christensen, 1986) under the SI+ST treatment. The treatment SI+ST gave a $2.9 \%$ higher dry matter over the SI treatment (Fig. 1). Our findings agree with Zhang et al. (2015), who have found that straw incorporation increased grain yield and biomass yield. Therefore, the application of Si with straw return should be considered an essential practice in maize farming for improving yield and promoting sustainable soil systems. 


\section{Total plant $N$ uptake and uptake rate}

Cuong et al. (2017) noted that the application of $\mathrm{Si}$ at the level of $329 \mathrm{~kg} \mathrm{hm}^{-2}$ with inorganic fertilizer would help in $\mathrm{N}$ uptake in rice. $\mathrm{Si}$ and $\mathrm{N}$ are said to have a synergistic effect, and Si can raise the optimum $\mathrm{N}$ rate in rice (Ho et al., 1980). Averaged over two years, the $\mathrm{N}$ uptake rate under the SI treatment increased by $10.4 \%$ than that under the $\mathrm{C}$ treatment (Table 4). We also found that the application of Si increased $\mathrm{N}$ uptake by $15.6 \%$ on average compared with the $\mathrm{N}$ uptake under the conventional practice (C) (Fig. 2). Our findings concerning the significant effect of Si to $\mathrm{N}$ uptake are broadly in line with Laîné et al. (2019).

Table 4. Logistic equation characteristics (Eq.1,2 and 3) of the $N$ uptake of the entire plant subjected to different Si and straw treatments in 2017 and 2018. $t_{1}$ : Time of total plant $N$ uptake acceleration $t_{2}$ : Time of whole plant $N$ uptake deceleration $T$ : The fast uptake period of total plant $N(d)$

\begin{tabular}{c|c|c|c|c|c|c|c}
\hline Years & Treatments & Regression equation & $\mathbf{R}^{\mathbf{2}}$ & $\begin{array}{c}\mathbf{t}_{1} \\
(\mathbf{d a y})\end{array}$ & $\begin{array}{c}\mathbf{t}_{\mathbf{2}} \\
(\mathbf{d a y})\end{array}$ & $\mathbf{T}$ (day) & Uptake rate $\left(\mathbf{k g ~ h a}^{-1} \mathbf{d}^{-1}\right)$ \\
\hline \multirow{4}{*}{2017} & $\mathrm{C}$ & $\mathrm{N}=188.8 /\left(1+60.1 \mathrm{e}^{-0.0714 t}\right)$ & $0.9970 *$ & 38.9 & 75.8 & 36.9 & $2.95 \mathrm{~d}$ \\
& $\mathrm{SI}$ & $\mathrm{N}=220.6 /\left(1+68.8 \mathrm{e}^{-0.0669 t}\right)$ & $0.9981 *$ & 43.6 & 82.9 & 39.4 & $3.24 \mathrm{~b}$ \\
& $\mathrm{ST}$ & $\mathrm{N}=205.8 /\left(1+56.8 \mathrm{e}^{-0.0693 t}\right)$ & $0.9940 *$ & 39.3 & 77.3 & 38.0 & $3.13 \mathrm{c}$ \\
& $\mathrm{SI}+\mathrm{ST}$ & $\mathrm{N}=236.6 /\left(1+89.4 \mathrm{e}^{-0.0657 t}\right)$ & $0.9989 *$ & 48.3 & 88.4 & 40.1 & $3.41 \mathrm{a}$ \\
\hline \multirow{3}{*}{2018} & $\mathrm{C}$ & $\mathrm{N}=164.8 /\left(1+188.7 \mathrm{e}^{-0.0746 t}\right)$ & $0.9901 *$ & 53.6 & 87.9 & 34.3 & $2.71 \mathrm{~d}$ \\
& $\mathrm{SI}$ & $\mathrm{N}=192.2 /\left(1+336.6 \mathrm{e}^{-0.0714 t}\right)$ & $0.9856 *$ & 63.1 & 99.9 & 36.9 & $3.01 \mathrm{~b}$ \\
& $\mathrm{ST}$ & $\mathrm{N}=174.6 /\left(1+390.4 \mathrm{e}^{-0.0744 t}\right)$ & $0.9872 *$ & 62.5 & 97.9 & 35.4 & $2.85 \mathrm{c}$ \\
& $\mathrm{SI}+\mathrm{ST}$ & $\mathrm{N}=213.4 /\left(1+390.4 \mathrm{e}^{-0.069 t}\right)$ & $0.9848 *$ & 67.4 & 105.6 & 38.2 & $3.23 \mathrm{a}$ \\
\hline
\end{tabular}

*, significant at $\mathrm{P}<0.05 ; * *$, significant at $\mathrm{P}<0.01$

Appropriate incorporation of straw has a positive effect on $\mathrm{N}$ mineralization and probably N uptake by rice crop (Takahashi et al., 2003). Zhang et al. (2016) demonstrated that the use of compost plus inorganic fertilizer as a practical nutrient management approach to maintain $\mathrm{N}$ uptake, reduce $\mathrm{N}$ loss and, increase soil fertility. It is evident from our study that straw return significantly improved $\mathrm{N}$ uptake by crop (Table 4). The $\mathrm{N}$ uptake rate under the SI+ST treatment increased by $3.8 \%$ on average than that under the SI treatment. Similarly, in treatment with the straw application (SI+ST), N uptake was 7.6\% higher than that with no straw treatment (SI) (Fig. 2). Similar results have been reported by $\mathrm{Hu}$ and Zhang (2017) that straw incorporation improved N uptake and NUE in rice.

\section{Remobilization of $N$ in spring maize}

During the vegetative phase, the leaves and stem are the sinks for $\mathrm{N}$; later, during senescence or deficiency periods, this $\mathrm{N}$ is re-translocated for reuse in the developing grain, fruits, and even young leaves (Okumoto and Pilot, 2011; Hernandez-Apaolaza, 2014). A balanced input of $\mathrm{N}$ and Si fertilizers showed an effect on agronomic indexes of rapeseed crops (Laîné et al., 2019). In this study, the remobilization amount, remobilization efficiency, and contribution to the grain under SI treatment increased by $21 \%, 4 \%$, and $6.8 \%$, respectively, compared to that under C (Table 2). The increase of remobilization under SI treatment was probably due to the application of Si fertilizer 
stimulated plants to take up more $\mathrm{N}$ (Neu et al., 2017) for remobilization. Our study corroborates with Detmann et al. (2012), who demonstrated that Si nutrition promoted N remobilization by stimulating amino acid remobilization from vegetative parts to the grains. Straw incorporation has the potential to affect agricultural management practices that improves soil nutrients (Zhou et al., 2018) as it is a readily available organic material which function to enhance soil fertility by releasing some nutrients such as N.P.K and others (Pathak et al., 2006). Organic matter applied in the form of liquid cattle manure increased $\mathrm{N}$ accumulation, distribution, and remobilization from leaves and stem to kernels (Dordas et al., 2008). In our study, straw application significantly affected the re-translocation of $\mathrm{N}$ (Table 2). The SI+ST treatment increased by $7.9 \%, 1.1 \%$, and $3.6 \%$ of $\mathrm{N}$ remobilization amount, remobilization efficiency, and $\mathrm{N}$ contribution to the grain, respectively, compared with that of the SI treatment. This study supported previous reports Wang et al. (2017) that manure plus urea improved $\mathrm{N}$ accumulation and remobilization in wheat.

\section{Si fertilization under straw return improved the NUE of maize}

The Si nutrient modified nitrogen (N) use efficiency (NUE) in rice (Yogendra et al., 2013; Cuong et al., 2017) and wheat (Yogendra et al., 2013). Higher NUE observed with the application of calcium silicate (Yogendra et al., 2013). This study has clearly shown a significant effect of Si fertilizer on the NUE of maize. In the plot that received $45 \mathrm{~kg} \mathrm{ha}^{-1}$ of sodium silicate, the agronomic $\mathrm{N}$ use efficiency (AEN), recovery $\mathrm{N}$ use efficiency (REN), and partial factor productivity of $\mathrm{N}$ (PFPN) was $13.6 \%, 44.9 \%$, and $4.9 \%$, respectively higher than that in the conventional practice plot (C). However, Si fertilizer under SI treatment decreased the physiological efficiency of $\mathrm{N}$ (PEN) in our results by $26.7 \%$ than that under the $\mathrm{C}$ treatment (Table 3). The result shows that there was a synergistic effect between $\mathrm{Si}$ and $\mathrm{N}$. This study was consistent with the results of $\mathrm{Si}$ and $\mathrm{N}$ fertilization in rice (Yogendra et al., 2014) and in wheat (Neu et al., 2017) that $\mathrm{Si}$ fertilizer enhances the NUE's except for the PEN. Moreover, the PEN decreased with the addition of Si fertilizer, which was in harmony with the findings of (Awgchew et al., 2017), who revealed a reduced PEN with increases of fertilizer. The main reason for this phenomenon may be that the amount of nitrogen absorbed by the leaves and stems on the ground is much higher than that of the control, which reduces the yield of grain per unit of nitrogen.

Straw return and appropriate tillage approach significantly enhanced grain yield and NUE in winter wheat (Jin et al., 2017). The inorganic fertilizer, coupled with organic fertilizer, increases $\mathrm{N}$ uptake in rice by improving soil properties and NUE (Iqbal et al., 2019). In this study, as expected, the Si fertilizer and straw application had a significant effect on NUE. The AEN, REN, and PFPN of the SI+ST treatment were 3.6\%, 17.6\%, and $1.3 \%$ higher than that of SI treatment (Table 3). The increased NUE by straw was probably attributed to the improved organic matter status since straw served as $\mathrm{N}$ source (Kongchum et al., 2007). These results agree with the findings of previous studies that straw return significantly increased NUE (Eagle et al., 2000). Thus, retention of Si fertilizer plus straw return can be an option practice to improve NUE in agricultural production. 


\section{Conclusion}

The use of silicon fertilizer can not only improve the $\mathrm{N}$ uptake and the $\mathrm{N}$ uptake rate of maize, but also promote the remobilization of nitrogen and the apparent contribution to grain $\mathrm{N}$, and ultimately improve the yield. In comparison to the sole Si fertilizer application, the application of silicon fertilizer with straw return can further enhance the above effects, and at the same time, improve agronomic use efficiency, recovery use efficiency, and $\mathrm{N}$ partial factor productivity. There is sufficient evidence to support the claim that Si fertilizer combined with straw was of great advantage not only at improving NUE and crop yield but also reducing the effect of fertilizer on the environment, thus attaining the goals of sustainable agriculture. In further studies, long term experiments on Si fertilizer with straw return should be conducted to get more data that can provide comprehensive results on the integration of Si fertilizer and straw return on N nutrient. In addition, more studies should focus on how straw materials can be used to replace the use of Si fertilizer.

Acknowledgments. The authors would like to appreciate the National Key Research and Development Program of China (Grant No. 2017YFD0300604) and the National Key Research and Development Program of China (Grant No. 2018YFD0300203) for financial support.

\section{REFERENCES}

[1] Agegnehu, G., Nelson, P. N., Bird, M. I. (2016): The effects of biochar, compost, and their mixture and nitrogen fertilizer on yield and nitrogen use efficiency of barley grown on a Nitisol in the highlands of Ethiopia. - Science of the Total Environment 569: 869-879.

[2] Amin, M., Ahmad, R., Ali, A., Aslam, M., Lee, D. (2016): Silicon fertilization improves the maize (Zea mays L.) performance under limited moisture supply. - Cereal research communications 44(1): 172-185.

[3] Awgchew, H., Gebremedhin, H., Taddesse, G., Alemu, D. (2017): Influence of Nitrogen Rate on Nitrogen use Efficiency and Quality of Potato (Solanum tuberosum L.) varieties at Debre Berhan, Central Highlands of Ethiopia. - International Journal of Soil Science 12: 10-17.

[4] Baligar, V., Fageria, N., He, Z. (2001): Nutrient use efficiency in plants. - Communications in Soil Science and Plant Analysis 32(7-8): 921-950.

[5] Chen, Y., Xiao, C., Chen, X., Li, Q., Zhang, J., Chen, F., Yuan, L., Mi, G. (2014): Characterization of the plant traits contributed to high grain yield and high grain nitrogen concentration in maize. - Field Crops Research 159: 1-9.

[6] Christensen, B. T. (1986): Straw incorporation and soil organic matter in macro-aggregates and particle size separate. - Journal of Soil Science 37(1): 125-135.

[7] Cuong, T. X., Ullah, H., Datta, A., Hanh, T. C. (2017): Effects of silicon-based fertilizer on growth, yield, and nutrient uptake of rice in the tropical zone of Vietnam. - Rice Sci 24(5): 283-290.

[8] Deng, F., Wang, L., Li, Q. P., Ren, W. J. (2018): Relationship between nitrogen accumulation and nitrogen use efficiency of rice under different urea types and management methods. - Archives of Agronomy and Soil Science 64(9): 1278-1289.

[9] Deshmukh, R. K., Ma, J. F., Bélanger, R. R. (2017): Role of silicon in plants. - Frontiers in Plant Science 8: 1858.

[10] Detmann, K. C., Araújo, W. L., Martins, S. C., Sanglard, L. M., Reis, J. V., Detmann, E., Rodrigues, F. Á., Nunes-Nesi, A., Fernie, A. R., Da-Matta, F. M. (2012): Silicon nutrition increases grain yield, which, in turn, exerts a feed-forward stimulation of photosynthetic 
rates via enhanced mesophyll conductance and alters primary metabolism in rice. - New Phytologist 196(3): 752-762.

[11] Dordas, C. A., Lithourgidis, A. S., Matsi, T., Barbayiannis, N. (2008): Application of liquid cattle manure and inorganic fertilizers affect dry matter, nitrogen accumulation, and partitioning in maize. - Nutrient Cycling in Agroecosystems 80(3): 283-296.

[12] Du, X., Chen, B., Zhang, Y., Zhao, W., Shen, T., Zhou, Z., Meng, Y. (2016): Nitrogen use efficiency of cotton (Gossypium hirsutum L.) as influenced by wheat-cotton cropping systems. - European Journal of Agronomy 75: 72-79.

[13] Du, X., Xi, M., Kong, L. (2019a): Split application of reduced nitrogen rate improves nitrogen uptake and use efficiency in sweet potato. - Scientific Reports 9(1): 1-11.

[14] Du, X., Xi, M., Kong, L. (2019b): Split application of reduced nitrogen rate improves nitrogen uptake and use efficiency in sweet potato. - Sci Rep 9(1): 14058.

[15] Eagle, A. J., Bird, J. A., Horwath, W. R., Linquist, B. A., Brouder, S. M., Hill, J. E., van Kessel, C. (2000): Rice yield and nitrogen utilization efficiency under alternative straw management practices. - Agronomy Journal 92(6): 1096-1103.

[16] Gao, L., Ma, L., Zhang, W., Wang, F., Ma, W., Zhang, F. (2009): Estimation of nutrient resource quantity of crop straw and its utilization situation in China. - Transactions of the Chinese Society of Agricultural Engineering 25(7): 173-179.

[17] González-Fontes, A., Navarro-Gochicoa, M. T., Ceacero, C. J., Herrera-Rodríguez, M. B., Camacho-Cristóbal, J. J., Rexach, J. (2017): Understanding calcium transport and signaling, and its use efficiency in vascular plants. - In: Hossain, M. A., Kamiya, T., Burritt, D. J., Phan Tran, L.-S., Fujiwara, T. (eds.) Plant Macronutrient Use Efficiency. Elsevier, pp. 165-180.

[18] Greger, M., Landberg, T., Vaculík, M. (2018): Silicon influences soil availability and accumulation of mineral nutrients in various plant species. - Plants 7(2): 41.

[19] Haddad, C., Arkoun, M., Jamois, F., Schwarzenberg, A., Yvin, J.-C., Etienne, P., Laîné, P. (2018): Silicon promotes the growth of Brassica napus L. and delays leaf senescence induced by nitrogen starvation. - Frontiers in plant science 9: 516.

[20] Haynes, R. H. (ed.) (1998): The Canadian system of soil classification. - $3^{\text {rd }}$ edition, Soil Classification Working Group, NRC Research Press.

[21] Hernandez-Apaolaza, L. (2014): Can silicon partially alleviate micronutrient deficiency in plants? A review. - Planta 240(3): 447-458.

[22] Ho, D., Yan, H. D., Lin, Z. H., Pu, Z. X. (1980): On the silicon supplying ability of some important paddy soils in South China.-In: Proceedings of the symposium on paddy soil. Nanjing China. PP 95.

[23] Hu, Y., Zhang, H. (2017): Optimizing nitrogen management strategy under wheat straw incorporation for higher rice production and nitrogen use efficiency. - Journal of Plant Nutrition 40(4): 492-505.

[24] Huang, S., Zhang, W., Yu, X., Huang, Q. (2010): Effects of long-term fertilization on corn productivity and its sustainability in an Ultisol of southern China. - Agriculture, Ecosystems \& Environment 138(1-2): 44-50.

[25] Iqbal, A., He, L., Khan, A., Wei, S., Akhtar, K., Ali, I., Ullah, S., Munsif, F., Zhao, Q., Jiang, L. (2019): Organic manure coupled with inorganic fertilizer: An approach for the sustainable production of rice by improving soil properties and nitrogen use efficiency. Agronomy 9(10): 651.

[26] Islam, A., Saha, R. (1969): Effects of silicon on the chemical composition of rice plants. Plant and Soil 30(3): 446-458.

[27] Jat, R. A., Wani, S. P., Sahrawat, K. L. (2012): Conservation agriculture in the semi-arid tropics: prospects and problems. -Advances in agronomy 117: 191-273.

[28] Jin, C., Zheng, M. J., Pang, D. W., Yin, Y. P., Han, M. M., Li, Y. X., Luo, Y. L., Xu, X., Yong, L., Wang, Z. L. (2017): Straw return and appropriate tillage method improve grain yield and nitrogen efficiency of winter wheat. - Journal of integrative agriculture 16(8): 1708-1719. 
[29] Jugal, K., Ramani, P. (2017): Effect of silicon on nitrogen use efficiency, yield, and N and Si contents in rice under loamy sand soil. - Research J Chem and Environ 21(4): 110-118.

[30] Kaya, C., Tuna, L., Higgs, D. (2006): Effect of silicon on plant growth and mineral nutrition of maize grown under water-stress conditions. - Journal of Plant Nutrition 29(8): 14691480 .

[31] Kongchum, M., DeLaune, R., Hudnall, W. H., Bollich, P. K. (2007): Effect of Straw Incorporation on 15N-Labeled Ammonium Nitrogen Uptake and Rice Growth. Communications in Soil Science and Plant Analysis 38(15-16): 2149-2161.

[32] Laîné, P., Haddad, C., Arkoun, M., Yvin, J. C., Etienne, P. (2019): Silicon Promotes Agronomic Performance in Brassica napus Cultivated under Field Conditions with Two Nitrogen Fertilizer Inputs. - Plants 8(5): 137.

[33] Lea, P. J., Azevedo, R. A. (2006): Nitrogen use efficiency. 1. Uptake of nitrogen from the soil. - Annals of Applied Biology 149(3): 243-247.

[34] Luz, J., Rodrigues, C., Goncalves, M., Coelho, L. (2008): The effect of silicate on potatoes in Minas Gerais, Brazil. - IV Silicon in Agriculture Conference 31: 67.

[35] Mi, G., Liu, J. A., Chen, F., Zhang, F., Cui, Z., Liu, X. (2003): Nitrogen uptake and remobilization in maize hybrids differing in leaf senescence. - Journal of Plant Nutrition 26(1): 237-247.

[36] Moe, K., Mg, K. W., Win, K. K., Yamakawa, T. (2017): Effects of Combined Application of Inorganic Fertilizer and Organic Manures on Nitrogen Use and Recovery Efficiencies of Hybrid Rice (Palethwe-1). - American Journal of Plant Sciences 8(5): 1043-1064.

[37] Neu, S., Schaller, J., Dudel, E. G. (2017): Silicon availability modifies nutrient use efficiency and content, C: N: P stoichiometry, and productivity of winter wheat (Triticum aestivum L.). - Scientific Reports 7: 40829.

[38] Okumoto, S., Pilot, G. (2011): Amino acid export in plants: a missing link in nitrogen cycling. - Molecular plant 4(3): 453-463.

[39] Omara, P., Aula, L., Oyebiyi, F., Raun, W. R. (2019): World Cereal Nitrogen Use Efficiency Trends: Review and Current Knowledge. - Agrosystems, Geosciences \& Environment 2: 180045.

[40] Owino-Gerroh, C., Gascho, G. (2005): Effect of silicon on low pH soil phosphorus sorption and uptake and growth of maize. - Communications in Soil Science and Plant Analysis 35(15-16): 2369-2378.

[41] Patel, R., Patel, K., Malav, J. (2017): Status of Silicon in Rice (Oryza sativa L.) and its Correlation with Other Nutrients under Typic ustochrepts Soil. - Int. J. Curr. Microbiol. App. Sci 6(12): 2598-2611.

[42] Pathak, H., Singh, R., Bhatia, A., Jain, N. (2006): Recycling of rice straw to improve wheat yield and soil fertility and reduce atmospheric pollution. - Paddy and Water Environment 4(2): 111.

[43] Perchlik, M., Tegeder, M. (2017): Improving plant nitrogen use efficiency through alteration of amino acid transport processes. - Plant Physiology 175(1): 235-247.

[44] Prieto, K. R., Echaide-Aquino, F., Huerta-Robles, A., Valério, H. P., Macedo-Raygoza, G., Prado, F. M., Medeiros, M. H., Brito, H. F., da Silva, I. G., Felinto, M. C. C. (2017): Endophytic bacteria and rare earth elements; promising candidates for nutrient use efficiency in plants. - In: Hossain, M. A., Kamiya, T., Burritt, D. J., Phan Tran, L.-S., Fujiwara, T. (eds.) Plant Macronutrient Use Efficiency. Elsevier, pp. 285-306.

[45] Reich, M., Aghajanzadeh, T., De Kok, L. J. (2014): Physiological basis of plant nutrient use efficiency-concepts, opportunities, and challenges for its improvement. - In: Hawkesford, M., Kopriva, De Kok, L. (eds.) Nutrient use efficiency in plants. Springer, pp. $1-27$.

[46] Sharma, L. K., Bali, S. K. (2018): A review of methods to improve nitrogen use efficiency in agriculture. - Sustainability 10(1): 51. 
[47] Singh, K. K., Singh, K., Singh, R., Singh, Y., Singh, C. S. (2006): Response of nitrogen and silicon levels on growth, yield and nutrient uptake of rice (Oryza sativa L.). - Oryza 43(3): 220-223.

[48] Takahashi, S., Uenosono, S., Ono, S. (2003): Short-and long-term effects of rice straw application on nitrogen uptake by crops and nitrogen mineralization under flooded and upland conditions. - Plant and Soil 251(2): 291-301.

[49] Wang, L., Wang, S., Chen, W., Li, H., Deng, X. (2017): Physiological mechanisms contributing to increased water-use efficiency in winter wheat under organic fertilization. - PloS one 12(6): e0180205.

[50] Wang, X., Jia, Z., Liang, L., Zhao, Y., Yang, B., Ding, R., Wang, J., Nie, J. (2018): Changes in soil characteristics and maize yield under straw returning system in dryland farming. Field Crops Research 218: 11-17.

[51] Wang, L., Yuan, X., Liu, C., Li, Z., Chen, F., Li, S., Wu, L., Liu, Y. (2019): Soil C and N dynamics and hydrological processes in a maize-wheat rotation field subjected to different tillage and straw management practices. - Agriculture, ecosystems \& environment 285: 106616.

[52] Watson, C., Atkinson, D., Gosling, P., Jackson, L., Rayns, F. (2002): Managing soil fertility in organic farming systems. - Soil use and management 18: 239-247.

[53] Xu, Y., Nie, L., Buresh, R. J., Huang, J., Cui, K., Xu, B., Gong, W., Peng, S. (2010): Agronomic performance of late-season rice under different tillage, straw, and nitrogen management. - Field Crops Research 115(1): 79-84.

[54] Xu, H., Lu, Y., Xie, Z. (2016): Effects of silicon on maize photosynthesis and grain yield in black soils. - Emirates Journal of Food and Agriculture 28(11): 779-785.

[55] Yang, J., Jiang, N., Chen, J. (2003): Dynamic simulation of nitrogen application level effects on rice yield and optimization analysis of fertilizer supply in paddy field. - Ying Yong Sheng Tai Xue bao, The journal of applied ecology 14(10): 1654-1660.

[56] Yogendra, N., Prakash, N., Malagi, M., Kumara, B., Mohan Kumar, R., Chandrashekar, N. (2013): Effect of calcium silicate on yield and nitrogen use efficiency (NUE) of wetland rice. - Plant Archives 13(1): 89-91.

[57] Yogendra, N., Kumara, B., Chandrashekar, N., Prakash, N., Anantha, M., Jeyadeva, H. (2014): Effect of silicon on real time nitrogen management in a rice ecosystem. - African Journal of Agricultural Research 9(9): 831-840.

[58] Zhang, W., Xu, M., Wang, B., Wang, X. (2009): Soil organic carbon, total nitrogen, and grain yields under long-term fertilizations in the upland red soil of southern China. Nutrient Cycling in Agroecosystems 84(1): 59-69.

[59] Zhang, P., Wei, T., Li, Y., Wang, K., Jia, Z., Han, Q., Ren, X. (2015): Effects of straw incorporation on the stratification of the soil organic $\mathrm{C}$, total $\mathrm{N}$, and $\mathrm{C}: \mathrm{N}$ ratio in a semiarid region of China. - Soil and Tillage Research 153: 28-35.

[60] Zhang, Y., Li, C., Wang, Y., Hu, Y., Christie, P., Zhang, J., Li, X. (2016): Maize yield and soil fertility with the combined use of compost and inorganic fertilizers on a calcareous soil on the North China Plain. - Soil and tillage research 155: 85-94.

[61] Zhou, D. X., Su, Y., Ning, Y. C., Rong, G. H., Wang, G. D., Liu, D., Liu, L. Y. (2018): Estimation of the Effects of Maize Straw Return on Soil Carbon and Nutrients Using Response Surface Methodology. - Pedosphere 28(3): 411-421.

[62] Zhu, H., Wu, J., Huang, D., Zhu, Q., Liu, S., Su, Y., Wei, W., Syers, J. K., Li, Y. (2010): Improving fertility and productivity of a highly-weathered upland soil in subtropical China by incorporating rice straw. - Plant and Soil 331(1-2): 427-437. 